\title{
Correction to: Responding Fails to Extinguish During Human-Laboratory Experiments of Resurgence
}

\section{Valdeep Saini $^{1}$}

Published online: 25 May 2021

(C) Association for Behavior Analysis International 2021

\section{Correction to: The Psychological Record https://doi.org/10.1007/s40732-021-00469-8}

The last names of 2 co-authors are misspelled and should be corrected as follows:

"Kate Derrenback" should be "Kate Derrenbacker".

"Arohan Rima" should be "Arohan Rimal".

The original article has been corrected.

Publisher's Note Springer Nature remains neutral with regard to jurisdictional claims in published maps and institutional affiliations.

The online version of the original article can be found at https://oi.org/ 10.1007/s40732-021-00469-8

Valdeep Saini

vsaini@brocku.ca

1 Department of Applied Disability Studies, Brock University, 1812

Sir Isaac Brock Way, St. Catharines, Ontario, Canada 